note on pheochromocytoma and renal hypertension. Journal of Urology, 79, 173.

Kaufman, J.J., MaRks, L.S. \& Smith, R.B. (1974) Stenosis of the renal artery and coexistent lesions. Surgery, Gynecology and Obstetrics, 139, 59.

Kerzner, M.S., Reeves, J.A., DeNyse, D. \& Claunch, B.C. (1968) Pheochromocytoma with renal artery compression in an identical twin. Archives of Internal Medicine, 121, 91.

MCBRIDE, J.W. \& FITZ, A. (1971) Renal artery stenosis, pheochromocytoma and erythrocytosis. American Journal of Medicine, 51, 403.
Rosenheim, M.L., Ross, E.J., Wrong, O.M., Hodson, C.J., DAviEs, D.R. \& SMITH, J.F. (1963) Unilateral renal ischemia due to compression of a renal artery by a pheochromocytoma. American Journal of Medicine, 34, 735.

Schwartz, S.I., LilleheI, R.C., Shires, G.T., SPEncer, F.C. \& StORer, E.H. (1974) Principles of Surgery, 2nd Edn, p. 1414. McGraw Hill, New York.

Weidmann, P., Siegenthaler, W., Ziegler, W.H., Sulser, H., Endres, P. \& Werning, C. (1969) Hypertension associated with tumors adjacent to renal arteries. American Journal of Medicine, 47, 528.

\title{
Correlation between anti-DNA antibody titre and psychiatric manifestations in systemic lupus erythematosus
}

\author{
Y. LEVO*
M.D. \\ A. I. PICK \\ M.D.

\begin{abstract}
Summary
A patient with systemic lupus erythematosus with predominant psychiatric involvement was followed during two psychotic exacerbations of her disease. A high correlation was found between disease activity and the titre of anti-DNA antibodies. Disease activity was preceded and accompanied by a high titre, while remission was associated with a low titre. The significance of this correlation for the pathogenesis, diagnosis and management of the psychiatric symptoms of systemic lupus erythematosus are discussed.
\end{abstract}

J. KALACI
M.D.

M. GolomB

M.D.

Department of Medicine B, Hypertensive-Renal Unit, and Section of Clinical Immunology, The Rogoff Institute for Medical Research, Geha Hospital, Beilinson Medical Center, The Sackler School of Medicine, Tel-Aviv University, Tel-Aviv, Israel

\section{Introduction}

Immune complexes, mainly of native DNA and its antibody, play a major role in the pathogenesis of systemic lupus erythematosus (SLE) (Koffler $e t$

\footnotetext{
* Present address: c/o Professor E. Franklin, Department of Medicine, New York University Medical Center, 550 First Avenue, New York, New York 10016, U.S.A.
}

al., 1971). A good correlation between high antiDNA antibody titres and low complement levels was observed during periods of active renal or cutaneous involvement in SLE patients (Oyama, 1971; Levo et al., 1973). The pathogenesis of central nervous system (CNS) involvement in SLE is possibly based on the same mechanisms (Bennett et al., 1972; Baker et al., 1974; Petz et al., 1971; Hadler et al., 1973; Keeffe, Baradana and Harbeck, 1974; Harbeck et al., 1973; Levin et al., 1972; Atkins et al., 1972; Bennahum and Messner, 1975). However, the correlation between cerebral manifestations in SLE patients and similar immunological parameters during various stages of their disease has not yet been established.

This report describes a patient with SLE with predominant psychiatric manifestations in whom a correlation was observed between serum anti-DNA antibody titres, complement levels and disease activity. 


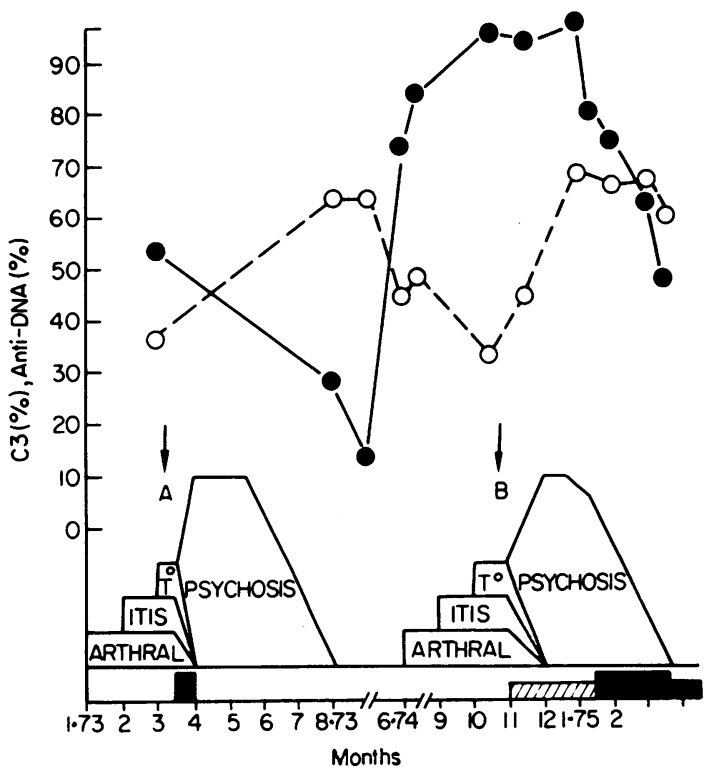

FIG. 1. The correlation of clinical activity and treatment with anti-DNA antibodies and complement (C3) levels in a patient with SLE. - - Anti-DNA antibody titres; $\bigcirc-. . \bigcirc$, complement (C3) levels. A and B, Admissions to hospital; ARTHRAL, arthralgia; ITIS, arthritis; $\mathrm{T}^{\circ}$, fever. $\square$, Prednisone; $\mathbb{Z}$, azathioprine.

\section{Case history}

A 28-year-old female was admitted to hospital in March 1973 because of arthritis, fever, and skin eruption (Fig. 1). In August 1972, a diagnosis of SLE was first made on the basis of arthritis, typical rash, leucopenia and a positive LE cell preparation. She was treated with aspirin and soon afterwards had a complete clinical remission. Her present relapse started in November 1972 with arthralgia, followed in February 1973 with actual arthritis, and when rash and fever supervened in March she was admitted to the Geha hospital, Tel-Aviv. Examination revealed arthritis of the proximal interphalangeal joints of both hands and both knees. An erythematousmacular rash of the hands and cheeks and erosions of the buccal mucosae were noted.

The relevant laboratory findings were: haemoglobin $9.9 \mathrm{~g} / 100 \mathrm{ml}$, white blood cell count (WBC) $3200 / \mathrm{mm}^{3}$; the Westergren sedimentation rate was $80 \mathrm{~mm} / \mathrm{hr}$. Blood urea nitrogen (BUN), creatinine clearance and urine analysis were normal. Numerous LE cells were found and the antinuclear antibody test was strongly positive. The $\mathrm{C} 3$ complement level determined according to Carpenter (1967) was 38 $\mathrm{mg} / 100 \mathrm{ml}$ (normal range 93-200), and the antiDNA antibody titre determined by radioimmunoassay according to Pincus et al. (1971) was 53\% (normal range 0-20). A kidney biopsy was per- formed. Light microscopy of the specimen was normal, but electron microscopy revealed small electron-dense deposits in the basement membrane and viral-like structures in endothelial cells.

Treatment was started with $60 \mathrm{mg}$ prednisone daily. The arthritis, fever and rash disappeared. However, 2 weeks later she became overtly psychotic with schizophrenic manifestations which necessitated her transfer to a psychiatric ward. The prednisone was immediately stopped and electro-shock therapy instituted. She was in the psychiatric ward for 4 months, during which time she had neither organic symptoms nor complaints, and received only large doses of phenothiazines. Psychiatric remission was achieved in August 1973, concomitant with a drop in anti-DNA titre to $13 \%$ and a normal sedimentation rate. However, complement $\mathrm{C} 3$ and $\mathrm{C} 4$ levels remained low, being $63 \mathrm{mg} / 100 \mathrm{ml}$ and $9 \mathrm{mg} / 100 \mathrm{ml}$ respectively. From September 1973 until May 1974 the patient was completely asymptomatic.

The next relapse began in May 1974, again with arthralgia. The severity of the arthralgia increased during the following 3 months and by September frank arthritis was noticed. In October, fever and further aggravation of the arthritis necessitated readmission (Fig. 1B). During these 5 months from May to October, there was a gradual increase in the anti-DNA antibody titre to $95 \%$, a rise in the sedimentation rate to $100 \mathrm{~mm} / \mathrm{hr}$, a drop in complement $\mathrm{C} 3$ level to $33 \mathrm{mg} / 100 \mathrm{ml}, \mathrm{C} 4$ level remained low, and repeated kidney function tests and urine analyses were normal.

During this time, azathioprine $100 \mathrm{mg} /$ day was administered. During the first week intramuscular tetracosactide $1 \mathrm{mg} /$ day was given as well. In the following 4 weeks fever and arthritis abated while both the sedimentation rate and the titre of antiDNA antibodies remained very high.

Towards the end of November the full-blown picture of a schizophrenic psychosis developed which once again necessitated transfer to a psychiatric ward. High doses of phenothiazines were immediately instituted. During the following 6 weeks there was a partial regression of the psychotic symptoms. The high sedimentation rate and the very high titre of anti-DNA antibody titre persisted, indicating continued SLE activity. Therefore, it was decided to add to the treatment regimen $60 \mathrm{mg}$ of prednisone daily. From this stage onward, during the next 2 months, there was a steady regression of all the remaining symptoms accompanied by a gradual decrease in both the anti-DNA antibody titre to $48 \%$ and the sedimentation rate. $\mathrm{C} 4$ level remained low, while a moderate increase in $\mathrm{C} 3$ levels from 33 to $\mathbf{7 0}$ $\mathrm{mg} / 100 \mathrm{ml}$ was noted.

The patient has been followed-up since her discharge from the hospital 3 months ago. She is in a 
complete clinical remission. The prednisone was tapered gradually to $15 \mathrm{mg} /$ day. Anti-DNA antibody titre continues to decrease while C3 and C4 levels remain unchanged.

\section{Discussion}

A growing amount of recently accumulated evidence indicates that the pathogenic mechanisms which underlie the cerebral manifestations of SLE are similar to those involved in the pathogenesis of lupus nephritis (Bennett et al., 1972; Baker et al., 1974; Petz et al., 1971; Hadler et al., 1973; Keeffe et al., 1974; Harbeck et al., 1973; Levin et al., 1972; Atkins et al., 1972; Bennahum and Messner, 1975). Hence, immune complexes of DNA and its antibody were found to be deposited on the basal membrane of the choroid plexus in SLE patients with CNS involvement (Atkins et al., 1972). Such complexes were also demonstrated in the cerebrospinal fluid (CSF) and in the serum of these patients (Keeffe et al., 1974; Harbeck et al., 1973). Recent observations (Petz et al., 1971; Hadler et al., 1973; Keeffe et al., 1974; Harbeck et al., 1973) have also suggested that increased activity of CNS disease in SLE patients might be accompanied by a rise in the anti-DNA antibody titre and a drop in the $\mathrm{C} 4$ complement level as monitored by serial examination of CSF samples.

Serum anti-DNA antibody titres are considered to be a most specific and sensitive parameter for the diagnosis and follow-up of SLE patients with renal involvement (Oyama, 1971; Pincus et al., 1971; Pick, Levo and Weiss, 1974). Determination of serum anti-DNA antibody titres together with serum levels of $\mathrm{C} 3$ and $\mathrm{C4}$ complement components have proved useful in the management of patients with SLE nephritis (Oyama, 1971; Pick et al., 1974). However, the usefulness of these laboratory parameters in patients with CNS involvement has not yet been established since very few SLE patients with such involvement have been followed-up (Bennett $\boldsymbol{e t}$ al., 1972; Keeffe et al., 1974; Harbeck et al., 1973). Most of these reported patients had pure neurological symptoms unaccompanied by psychiatric manifestations.

The present patient has been followed-up through two episodes of SLE activity which were predominantly manifested by psychiatric symptoms. In both episodes there was a marked correlation between the degree of the psychosis and the titre of serum anti-DNA antibodies. Each time, a slowly rising titre of the antibodies reached its peak just before the psychotic relapse began and gradually decreased with regression of the symptoms (Fig. 1).

Both psychotic relapses in the patient evolved through a very peculiar somatic prodrome. This prodrome was initially manifested by arthralgia, followed by overt episodes of arthritis, then by a typical skin eruption, finally culminating in fever. The fever marked the turning point from which time all somatic symptoms gradually cleared, within 1 month. The psychotic flare-up immediately followed the abatement of the somatic symptoms (Fig. 1).

The somatic prodromal stage of the psychotic exacerbations lasted each time about 5 months. During this period, both the anti-DNA titre and the sedimentation rate gradually rose to their peaks.

CNS involvement is more common in SLE patients without renal involvement (Petz et al., 1971; Cheatum et al., 1973). The present patient could have passed as such, since repeat kidney function tests and urine analyses and even the light microscopy study of her renal biopsy specimen were normal. However, the ultrastructural study of the biopsy specimen revealed the characteristic features of SLE nephritis. Hence, minimal renal damage is possibly much more frequent in SLE patients with CNS involvement.

To conclude, it seems that DNA-anti-DNA complexes play a pathogenic role even in patients whose SLE is predominantly manifested by psychiatric symptoms. In these patients anti-DNA antibody titres are of great importance in the diagnosis, early detection, follow-up and adjustment of therapy similar to their importance in patients with predominant renal involvement.

A high anti-DNA antibody titre, being specific for SLE activity, may be helpful for the distinction of SLE-related psychosis from steroid-induced psychosis, and should be considered as an indication for active corticosteroid treatment.

\section{Acknowledgments}

The authors thank Dr M. Ben-Bassat and Ms Ch. Weiss for their help in the pathological, ultrastructural and immunological studies.

\section{References}

Atkins, C.J., Kondon, J.J., Quismorio, F.P. \& Friou, G.J. (1972) The choroid plexus in systemic lupus erythematosus. Annals of Internal Medicine, 76, 65.

BAKER, M., HADler, N.M., Whitaker, J.N., DUNner, D.L., Gerwin, R.D. \& DeCker, J.L. (1974) Psychopathology in systemic lupus erythematosus. II. Relation to clinical observations, corticosteroid administration and cerebrospinal fluid C4. Seminars of Arthritis and Rheumatism, 3, 111.

BenNahum, D.A. \& Messner, R.P. (1975) Recent observations on central nervous system lupus erythematosus. Seminars of Arthritis and Rheumatism, 4, 253.

BenNetT, R., Hughes, G.R.V., Bywaters, E.G.L. \& Holt, P.J.L. (1972) Neuropsychiatric problems in systemic lupus erythematosus. British Medical Journal, 4, 342.

CARPENTER, B.C. (1967) Instability of the complement system in patients with renal allografts. Transplantation, 5, 864.

Cheatum, D.E., Hurd, E.R., Strunk, S.W. \& Ziff, M. (1973) Renal histology and clinical course of systemic lupus erythematosus. Arthritis and Rheumatism, 16, 670. 
Hadler, N.M., Gerwin, R.D., Franklin, M.M., Whitaker, J.N., BAKER, M. \& DECKER, J.L. (1973) The fourth component of complement in the cerebrospinal fluid in systemic lupus erythematosus. Arthritis and Rheumatism, 16, 507.

Harbeck, R.J., Hoffman, A.A., Carr, R.I. \& Baradana, E.J. (1973) DNA antibodies and DNA: anti-DNA complexes in cerebral spinal fluid of patients with systemic lupus erythematosus. Arthritis and Rheumatism, 16, 552.

KeEFFe, E.B., BaRAdana, E.J., Jr \& HaRbeck, R.J. (1974) Lupus meningitis. Annals of Internal Medicine, 80, 58.

Koffler, D., Agnello, V., Thoburn, R. \& Kunkel, H.G. (1971) Systemic lupus erythematosus prototype of immune complex nephritis in man. Journal of Experimental Medicine, 134, 169.

Levin, A.S., Fudenberg, H.H., Petz, L.D. \& Sharp, G.C. (1972) IgG levels in cerebrospinal fluid of patients with central nervous system manifestations of systemic lupus erythematosus. Clinical Immunology and Immunopathology, $1,1$.
Levo, Y., Pick, A.I., Nir, M.A., Weiss, C. \& Feuerman, E.J. (1973) Correlation between immunological parameters and cutaneous manifestations of systemic lupus erythematosus. Dermatologia. 147, 316.

OYAMA, J.H. (1971) Diagnosis and treatment of lupus nephritis. Medical Clinics of North America, 55, 71.

Petz, L.D., SharP, G.C., CoOper, N.R. \& Irvin, W.S. (1971) Serum and cerebral spinal complement and serum autoantibodies in systemic lupus erythematosus. Medicine, 50, 259.

Pick, A.I., Levo, Y. \& Weiss, C. (1974) The value of antiDNA antibody titers in the early diagnosis, treatment and followup of systemic lupus erythematosus. Israel Journal of Medical Sciences, 10, 725.

Pincus, T., Hughes, G.R.V., Pincus, D., Tina, L.V. \& Bellanti, J.A. (1971) Antibodies to DNA in childhood systemic lupus erythematosus. Journal of Pediatrics, 78, 981.

Postgraduate Medical Journal (December 1976) 52, 798-800.

\title{
Alpha-chain disease in an Englishman
}

\author{
S. W. S. WANG* \\ M.B., Ch.B., M.R.C.P. \\ Liverpool Royal Infirmary
}

\begin{abstract}
Summary
Eighty cases of the gastro-intestinal form of alphachain disease had been reported up to the time of writing this communication (September 1975). All patients were non-Caucasians. This report presents a case of this disorder in an Englishman who became ill whilst working in the tropics. His clinical features and response to therapy were entirely in line with the other cases so far reported.
\end{abstract}

\section{Introduction}

The first case of alpha-chain disease was described in 1968 (Ramboud et al., 1968; Seligman et al., 1968). By July 1975 a total of eighty cases had been reported (Doe et al., 1972; Manousos et al., 1974; Seligmann, 1975a, b).

Abdominal pain, weight-loss, steatorrhoea and marked finger clubbing are the main features (Ramboud and Matuchansky, 1973; Seligmann, 1975c).

\footnotetext{
* Present address: Department of Cardiology, Manchester Royal Infirmary, Oxford Road, Manchester M13 9WL.
}

A case is now reported where the presenting features were vomiting due to upper intestinal obstruction, weight-loss, steatorrhoea, anaemia and occult gastro-intestinal tract bleeding, and finally response to treatment with cyclophosphamide, prednisolone and tetracycline was achieved.

\section{Case history}

The patient, an Englishman, was first seen in 1966 (when he was 31 years old) at the School of Tropical Medicine, Liverpool, with a 7-month history of vomiting and diarrhoea, which had developed while he was working in Cameroon, West Africa. He had earlier worked for 3 years in Mauritius. Apart from having had 'stomach trouble' as an adolescent, there had been no significant illnesses in the past.

In December 1965 he developed vomiting and diarrhoea which lasted for about 1 week and then improved, but there were several recurrences in the course of the next few months. In July 1966 he developed severe and persistent vomiting and diarrhoea. He was sent back to Britain for medical 